\title{
Planktonic availability and settlement of Carcinus maenas megalopae at high temporal resolution in the lower Mira Estuary (SW Portugal)
}

\author{
Valter Amaral ${ }^{1, *}$, Henrique Queiroga ${ }^{2}$, Martin Skov ${ }^{1,3}$, José Paula ${ }^{1}$ \\ ${ }^{1}$ Laboratório Marítimo da Guia, Faculdade de Ciências da Universidade de Lisboa, \\ Avenida Nossa Senhora do Cabo 939, 2750-374 Cascais, Portugal \\ ${ }^{2}$ Departmento de Biologia, Universidade de Aveiro, Campus Universitário de Santiago, 3810-193 Aveiro, Portugal \\ ${ }^{3}$ Present address: School of Biological Sciences, University of Southampton, Bassett Crescent East, \\ Southampton SO16 7PX, UK
}

\begin{abstract}
The current conceptual model of reinvasion and settlement for estuarine brachyuran crabs in mesotidal systems is that megalopae undergo selective tidal stream transport, in an upstream direction, and settle by the end of the flood tide. Recent studies on recruitment processes of Carcinus maenas (L.) have reported a clear decoupling between supply, as larval influx, and settlement events in the lower Mira Estuary (SW Portugal). We investigated, at high temporal resolution, whether overestimation of planktonic abundances and/or deviations of megalopal responses from the conceptual model were responsible for such decoupling. Daily settlement of megalopae was analyzed using regression and spectral analyses to identify periodicities and correlated with tidal amplitude. Hydrological parameters and supply, net flux and hourly concentration of megalopae in the plankton were addressed as factors influencing short, intermediate and long-term settlement, through $50 \mathrm{~h}$ sampling series. Supply and surface net flux levels of megalopae were similar and clearly decoupled from settlement on bottom-deployed collectors. Both hourly planktonic concentration and settlement patterns of megalopae fitted the conceptual model at high temporal resolution, with some deviations in terms of light intensity influences. Furthermore, our results suggest that processes preventing settlement and capable of overriding the influence of light intensities - such as turbulence - may explain the decoupling between supply and settlement of shore crab megalopae in the lower Mira Estuary.
\end{abstract}

KEY WORDS: Settlement · Supply · Net flux · Decoupling $\cdot$ Megalopae $\cdot$ Tidal and semilunar rhythms · Carcinus maenas $\cdot$ Bottom-deployed collectors

\section{INTRODUCTION}

Newly hatched larvae of many estuarine decapod crustaceans are exported to coastal waters where they may remain for days or months. By the end of planktonic development, larvae must return to habitats where benthic settlement takes place. These are critical events that involve larval behavioural and physiological adaptations, as well as environmental processes.
The conceptual model of reinvasion and settlement for estuarine brachyuran crabs in mesotidal systems suggests that megalopae are transported upstream during flood tide by selective tidal stream transport (STST) (Little \& Epifanio 1991, Zeng \& Naylor 1996, Queiroga 1998, Forward \& Tankersley 2001), and settle by the end of the flood tide (Zeng et al. 1997, Tankersley et al. 2002). Megalopae undergoing STST ascend in the water column in response to increasing salinity associated with the flood tide and are stimu- 
lated to swim by high turbulence levels (De Vries et al. 1994, Tankersley et al. 1995, Welch et al. 1999, Welch \& Forward 2001). After mid-flood tide, megalopae are cued to descend and settle by decreasing turbulence and current speed, being inhibited from swimming during the ebb tide by decreasing salinity (Welch \& Forward 2001, Tankersley et al. 2002). Swimming is also inhibited by light, causing STST and settlement to occur mainly during darkness (Tankersley et al. 1995, Zeng \& Naylor 1996, Queiroga 1998, Forward et al. 2004).

Hatching in the portunid shore crab Carcinus maenas (L.) occurs on nocturnal ebb tides during spring and early summer, with larvae being exported to adjacent shelf waters (Paula 1989, Zeng \& Naylor 1997). Within 4 to $10 \mathrm{wk}$, depending on temperature, larvae develop through 4 zoeal stages (before metamorphosing into megalopae) and reinvade estuarine waters (Dawirs 1985, Nagaraj 1993). In Portuguese coastal waters, larval release occurs during neap tides (quarter moon periods) (Paula 1989, Queiroga et al. 1994), while supply, as larval influx back to estuarine waters, occurs during spring tides (new and full moon periods) (Almeida \& Queiroga 2003, Queiroga et al. 2006).

One of the most interesting findings on shore crab recruitment processes in the Mira Estuary (SW Portugal) is that maximum settlement occurs around neap tides, clearly decoupled from supply (Paula et al. 2006, Queiroga et al. 2006). Queiroga et al. (2006) proposed that this could result from (1) density-dependent secondary dispersal by settled megalopae, i.e. a large number of settling megalopae are offset by those leaving after settlement because of crowding, (2) supply from a pool of larvae in an early developmental stage, and/or (3) higher turbulence levels preventing megalopae from settling during spring tides. However, these explanations are yet to be tested, since data available on shore crab recruitment have been obtained with daily or lower frequencies, and higher temporal resolution is required to examine tidal processes. In addition, supply is a measure of megalopal invasion of estuarine waters, which does not consider the possibility of megalopae being carried out on ebb tides (Zeng \& Naylor 1996). If significant numbers of megalopae are carried out, especially with the stronger currents of spring tides, supply patterns might not correctly describe the real abundance levels of megalopae in the Mira Estuary, and thus bear no relationship with settlement events. In this case, net flux, as the balance between megalopae entering and leaving the estuary, would be a more accurate measure of planktonic abundance of megalopae. Furthermore, in the Mira Estuary settlement has been assessed only on intertidal collectors, without considering the possibility of this being a mainly subtidal event, especially during spring tides. In this case, the decoupling pattern would be an artefact caused by underestimation of subtidal settlement intensity during spring tides.

This study was set up to investigate the decoupling between supply and settlement of shore crab megalopae in the lower Mira Estuary. We assessed such events at high temporal resolution and their relationship to hydrological parameters and lunar, diel and tidal cycles. Our aim was to determine whether upstream movement and settlement of megalopae conform to the conceptual model for brachyuran crabs during spring and neap tides, or whether deviations from the model are responsible for the decoupling pattern. Specifically, our hypotheses were as follows: (1) supply levels of megalopae are similar to net flux levels during spring and neap tides, i.e. the majority of megalopae entering the estuary remain there; (2) the decoupling pattern is an artefact attributable to underestimation of settlement intensity, resulting from density-dependent secondary dispersal of settled megalopae during spring tides; (3) the decoupling pattern is an artefact attributable to using only intertidal collectors when settlement is mainly subtidal during spring tides; (4) both upstream movement and settlement of megalopae follow the conceptual model during spring and neap tides. In order to test these hypotheses, abundances of shore crab megalopae, from a combination of planktonic passive nets and tows and bottom-deployed collectors with different immersion periods and locations on the shore, were obtained and related to hydrological parameters and environmental cycles.

\section{MATERIALS AND METHODS}

Sampling. Sampling was conducted on a sandy beach, approximately $1 \mathrm{~km}$ inside the Mira Estuary $\left(37^{\circ} 40^{\prime} \mathrm{N}, 8^{\circ} 40^{\prime} \mathrm{W}\right)$ (Fig. 1). The Mira Estuary is a single-channel system with a semidiurnal tidal regime of $12.4 \mathrm{~h}$ and ca. $3.5 \mathrm{~m}$ maximum amplitude; tidal influence extends for $40 \mathrm{~km}$ inland. On average, tidal penetration ranges from 2.5 to $7.5 \mathrm{~km}$ during neap and spring tides, respectively (Paula 1989). Water column structure varies from vertically homogeneous to slightly stratified during spring and neap tides, respectively (Blanton \& Andrade 2001).

Lunar and daily settlement patterns of Carcinus maenas megalopae were assessed from 7 March to 8 June, 2003 on artificial hog's hair collectors $(0.4 \times$ $0.5 \times 0.02 \mathrm{~m}$, see Amaral \& Paula [2007]). Collectors $(n=4)$ were bottom-deployed on the intertidal zone every day at low tide and sampled after 2 tidal cycles (daily series). 


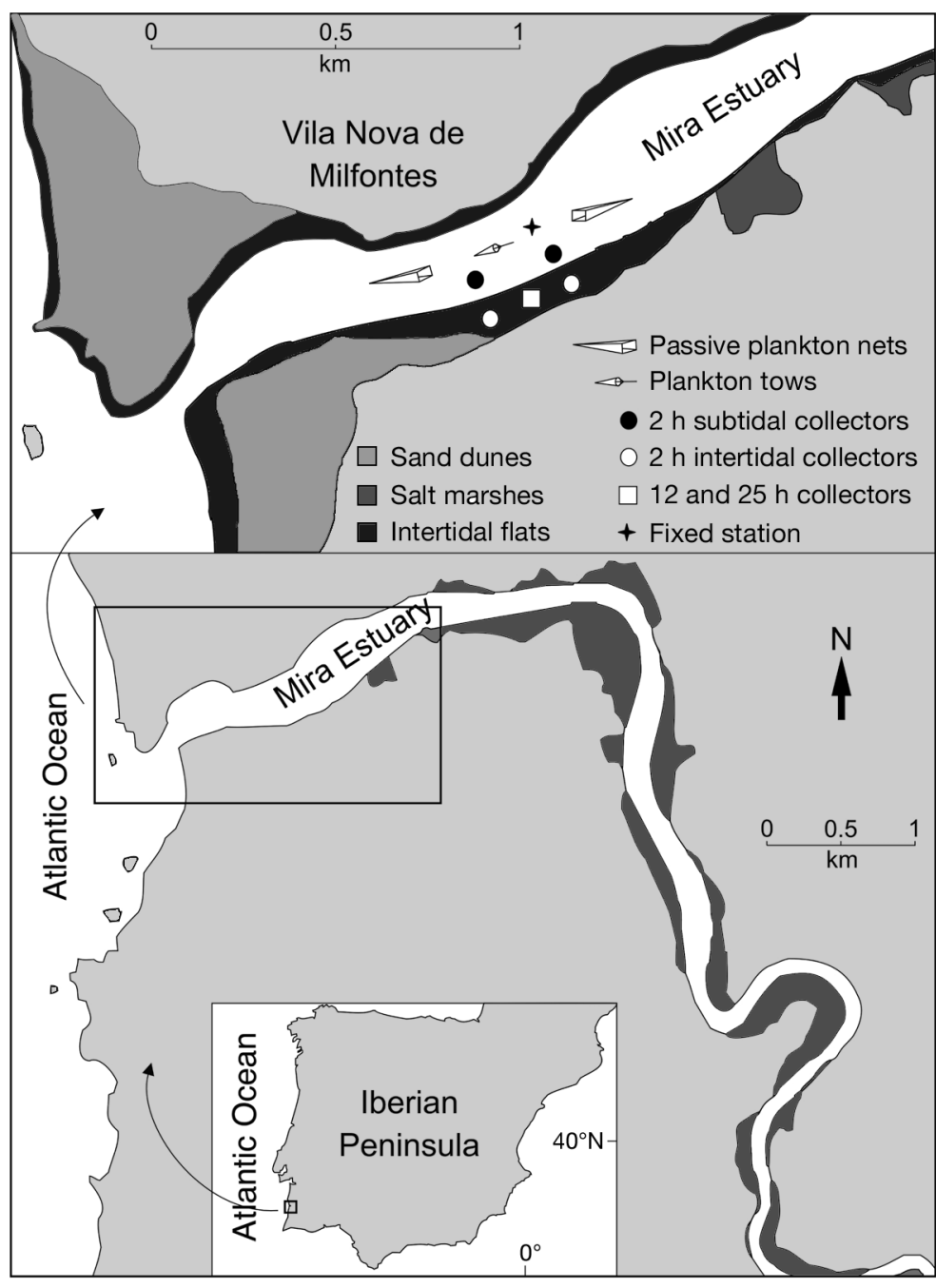

Fig. 1. Sampling area, Mira Estuary, Iberian Peninsula and deployment of plankton nets and collectors

We designed $50 \mathrm{~h}$ (4 tidal cycles) sampling series to study the effects of diel and tidal cycles on planktonic availability and settlement patterns of megalopae at high temporal resolution. Two spring and 2 neap tide sampling periods were planned. Unfortunately, due to relatively low settlement intensity, only 1 settlement event of proximate magnitude to those reported by Queiroga et al. (2006) was identified beforehand throughout the daily series. Thus, only 1 period of each type was sampled. The effects of spring and neap tides were examined from 19 to 21 March and 6 to 8 June, 2003, respectively. In both periods, planktonic availability of megalopae was estimated as supply, net flux and hourly concentration, and these were addressed as factors influencing settlement. Supply is a measure of total megalopal invasion of the estuary during flood tides, while net flux further integrates megalopae that are carried out on ebb tides, thus measuring the popu- lation remaining within estuarine boundaries. Both supply and net flux were measured using passive plankton nets, which were specifically designed for sampling only during tidal flows that they face. Two passive plankton nets, each facing a tide direction, were deployed just below the surface and ca. $0.2 \mathrm{~m}$ above the bottom and were sampled every 2 tidal cycles (Fig. 1). These nets were $2 \mathrm{~m}$ long, with a $0.10 \mathrm{~m}^{2}$ mouth opening and $500 \mathrm{~mm}$ mesh; an internal funnel collapses during opposite tidal flows to prevent collected material escaping (see Queiroga et al. 2006 for details). Supply was assessed from the contents of nets facing flood tides, and net flux from the balance between contents of nets facing flood and ebb tides, at each water depth. Hourly concentration was assessed with surface plankton tows $(5 \mathrm{~min})$ performed each hour along the sampling area (Fig. 1). A conical, $330 \mu \mathrm{m}$ mesh net, with $0.05 \mathrm{~m}^{2}$ mouth opening equipped with a flowmeter, was used. Settlement was assessed on bottom-deployed collectors $(\mathrm{n}=4)$ on short, intermediate and daily time frames. Short-term collectors $(2 \mathrm{~h})$ were deployed both intertidally and subtidally and sampled every $2 \mathrm{~h}$. Intermediate-term $(12 \mathrm{~h})$ and daily $(25 \mathrm{~h})$ collectors were deployed only intertidally and sampled every tidal and every 2 tidal cycles, respectively (Fig. 1). To assess cumulative settlement, $12 \mathrm{~h}$ collectors were always deployed in the same place. Megalopae captures were related to hourly measurements of water level, salinity, temperature and current speed conducted at a fixed station at 3 depths: just below the surface, in the middle of the water column and above the bottom (Fig. 1).

Collectors of each set were deployed randomly, 2 to $4 \mathrm{~m}$ apart from each other, in similar metal frames to prevent movement caused by water currents (Amaral $\&$ Paula 2007). Crab megalopae and juveniles were recovered by immersing the collectors in freshwater, rinsing them with freshwater jets through a $0.5 \mathrm{~mm}$ sieve and sorting out the animals from the debris. Passive plankton net and tow samples were immediately preserved in $4 \%$ formalin, and later sorted for crab megalopae and juveniles.

Statistical analysis. Periodic regression analysis was performed to estimate the period and amplitude of daily settlement in relation to the lunar cycle. A correction of the sinusoidal model for sharply peaked sinusoidal oscillations, evidenced by visual inspection of 
the data, was applied using nonlinear least-squares regression analyses (Batschelet 1981):

$$
Y=M+A \cos \left[\left(\frac{2 \pi t}{\lambda}-\theta\right)+v \sin \left(\frac{2 \pi t}{\lambda}-\theta\right)\right]+e
$$

where $Y$ is the dependent variable, $M$ is the mean level of $Y, A$ is the $Y$ amplitude, $t$ is the time when the sample was collected, $\lambda$ is the period length, $\theta$ is the acrophase angle, $v$ is the peakedness parameter and $e$ is the random error term. One problem with this correction is the appearance of undesired oscillations when $-1.05 \leq v \leq 1.05$. No attempt was made to adjust the model to diel differences or asymmetries in the amplitude of peaks. The regression coefficient $\left(\mathrm{R}^{2}\right)$ provides an estimate of the proportion of variation in the dependent variable accounted for by the sinusoidal model. Daily settlement values were $\log (x+1)$ transformed prior to analysis to down-weight large numbers. Spectral analysis (Chatfield 1996) was used to investigate settlement periodicities related to differences between waxing and waning, and new and full moon periods. Kolmogorov-Smirnov $d$ statistic was used to assess the significance level of spectral analysis. The relation between daily settlement and tidal amplitude was determined by a non-parametric Spearman correlation analysis.

Periodic regression analysis was also performed to estimate period and amplitude of hourly concentration of megalopae and settlement on $2 \mathrm{~h}$ collectors, in relation to the tidal cycle. Such analyses were made using $\lambda$ obtained for water level data of each respective $50 \mathrm{~h}$ sampling period. For both periods, supply was compared with megalopae captures on passive nets facing ebb tides using Student's $t$-tests. Net flux of megalopae was calculated for each depth, and also compared using Student's $t$ tests. These analyses were conducted on the number of megalopae captured by each net type, since standardization by volume would be subject to a large error (Queiroga et al. 2006). Settlement on $25 \mathrm{~h}$ and cumulative settlement on $12 \mathrm{~h}$ collectors were compared using Student's $t$-tests.

Regression analysis confirmed that megalopae abundances were consistently higher during flood tides, and thus light vs. dark comparisons were only performed on such data. Although flood tides occurring during dark hours were entirely nocturnal during the spring tide period and only crepuscular during the neap tide period, both kinds were defined as night-influenced tides. Light vs. dark comparisons were performed on hourly concentration of megalopae and settlement on 2 and $12 \mathrm{~h}$ collectors by Student's $t$-tests.

\section{RESULTS}

\section{Daily series}

Settlement of shore crab megalopae was clearly more intense around quarter moons during neap tides (Fig. 2B). This semilunar periodicity was confirmed by periodic regression and correlation analysis. Periodic regression of the settlement series showed a period of $14.7 \mathrm{~d}\left(\mathrm{R}^{2}=0.34\right)$, and correlation analysis indicated a strong relationship of settlement with days of lowest tidal amplitude ( $\mathrm{r}=-0.614, \mathrm{p}<0.001)$ (Fig. 2A). Relatively high settlement was recorded in spring tides from Days 74 to 76 , when the sampling area remained submerged for $3 \mathrm{~d}$, due to a sea storm. Spectral analysis detected 2 major peaks at periods of 94.0 and $15.7 \mathrm{~d}$, and 3 other minor peaks $(d=0.439, \mathrm{n}=94, \mathrm{p}<$ 0.005) (Fig. 3). The first peak is an artefact of the statistic (it is equal to the number of samples: 94). The $15.7 \mathrm{~d}$ period of the second peak further supports the semilunar settlement periodicity. No periodicity related to differences between waxing and waning or new and full moon periods (ca. 29.5 d) was detected.

\section{$50 \mathrm{~h}$ series}

\section{Hydrological parameters}

Water level showed the expected semilunar and semidiurnal tidal regimes, varying from 4.3 to $8.7 \mathrm{~m}$ and 5.2 to $7.3 \mathrm{~m}$ during the spring and neap tide periods, respectively (Table 1, Figs. 4A \& 5A). Salinity

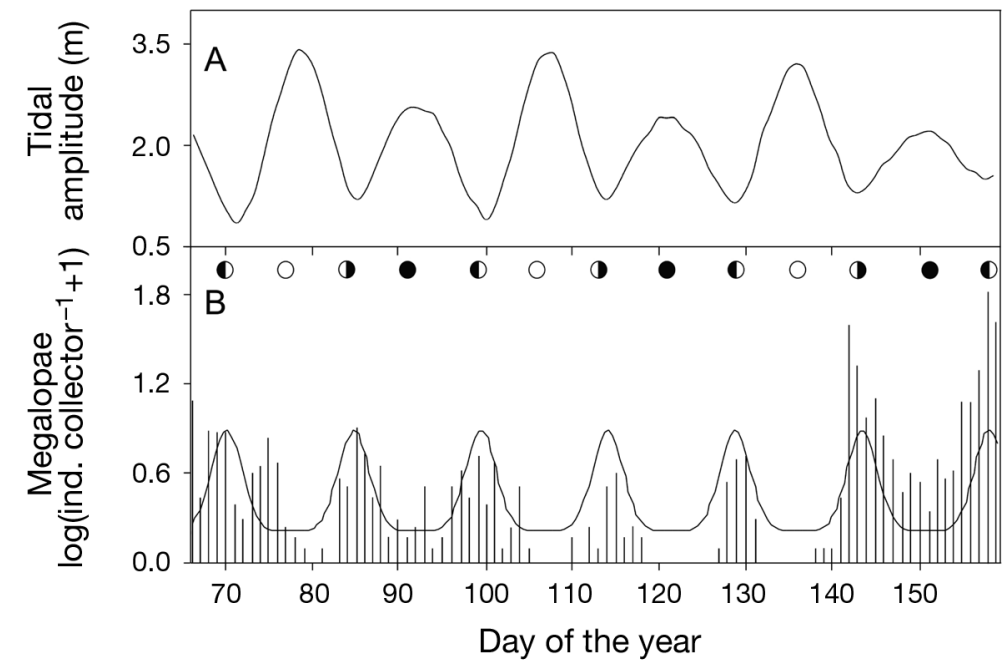

Fig. 2. Carcinus maenas. (A) Tidal amplitude. (B) $\log (\mathrm{x}+1)$ mean daily settlement of megalopae on collectors. Full, new, waxing and waning moons are represented by $\mathrm{O}, \boldsymbol{\bullet}, \mathbf{D}$ and $\mathbf{C}$, respectively. Curve represents fitting of a sinusoidal model using nonlinear least-squares regression analysis (see Table 1) 


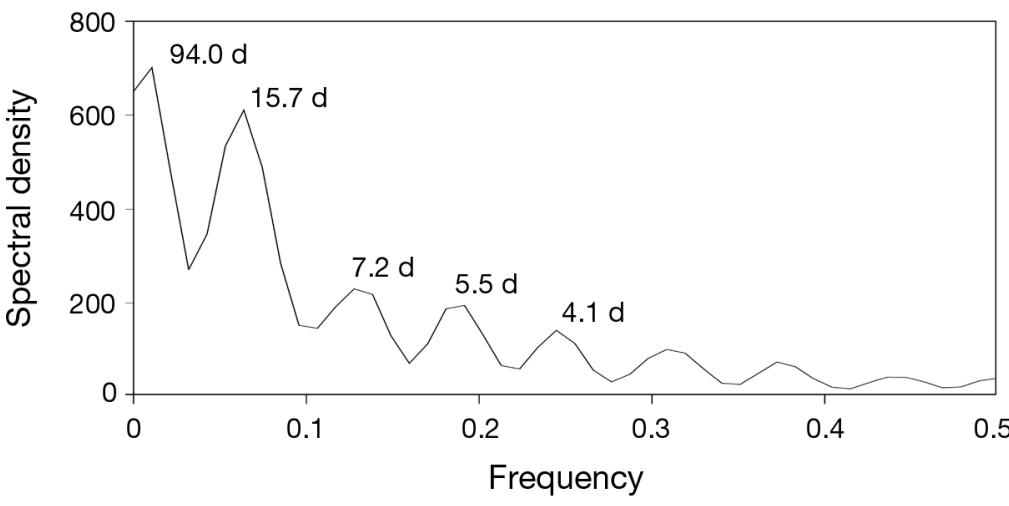

Fig. 3. Carcinus maenas. Spectral analysis of mean daily number of megalopae on collectors. Numbers above peaks represent the period of oscillation

values were similar during both periods. However, some stratification occurred during the last tidal cycle in the spring tide period, most probably due to heavy rainfall, but also in the neap tide period, especially during ebb tides (Figs. 4A \& 5A). Temperature stratification patterns were similar to those recorded for salinity, but amplitude and absolute values were higher during the neap tide period (Figs. 4B \& 5B). Water current speed varied from $0.0 \mathrm{~m} \mathrm{~s}^{-1}$ above the bottom, to 1.14 and $0.71 \mathrm{~m} \mathrm{~s}^{-1}$ at the surface, during the spring and neap tide periods, respectively. During both periods, current speeds were generally higher near the surface, especially during mid-tidal phases, when peaks were recorded at all depths (Figs. 4C \& 5C). These peaks, and respective amplitude changes, were of much higher intensity during the spring tide period.

\section{Planktonic availability}

Supply was clearly more intense (by a factor of about 2) during the spring tide than during the neap tide period (Table 2). The fact that considerably fewer megalopae were captured on the surface net facing flood tides during the second day of the neap tide period is reflected in the larger SEs obtained, explaining the lack of significant differences found in this period (Table 2). Caution should thus be taken in analyzing these results. Megalopal captures on passive nets facing ebb tides were much lower than those on nets facing flood tides during both periods, suggesting that the majority of megalopae remained inside the estuary. Accordingly, supply was similar to surface net flux of megalopae during both periods (Table 2). Megalopal net flux was higher at the surface than at the bottom during both periods, although.

Hourly concentration of megalopae was similar during both sampling periods. Periodic regression analyses also revealed strong tidal periodicities of hourly concentration of megalopae during both periods: during flood tide, concentration increased with increasing salinity and decreased concurrently with current speed, in agreement with upstream movement by STST (Table 1, Figs. 4, 5, 6B \& 7B). Despite the similar patterns, significantly higher abundances were detected on nightinfluenced flood tides during the neap tide period $(t=$ $-2.948, \mathrm{p}<0.01)$, but not during the spring tide period $(t=-0.299, \mathrm{p}=0.767)$.

\section{Settlement}

Following the semilunar pattern, settlement was higher during the neap than during the spring tide period. In fact, settlement on $2 \mathrm{~h}$ collectors was extremely low throughout the spring tide period: only in 2 out of 7 settlement events on intertidal collectors, and in 1 out of 5 on subtidal collectors, were more than 1 megalopae collected (Table 1, Fig. 6C,D). Settlement was also very low on 12 and $25 \mathrm{~h}$ collectors and, despite the outcome of statistical analysis, no reliable conclusions can be drawn from such data. Nevertheless, cumulative settlement on $12 \mathrm{~h}$ collectors was

Table 1. Results of periodic regression analyses for water level and for Carcinus maenas megalopae captures on plankton tows and on $2 \mathrm{~h}$ intertidal and subtidal collectors during the spring and neap tide periods. Period length estimates $(\lambda, \mathrm{h})$ for water level were used to fit the remaining sinusoidal model parameters ( $\theta$ : acrophase; $M$ : mean level; $A$ : amplitude; $\mathrm{R}^{2}$ : regression coefficient) for megalopal captures on plankton tows and on $2 \mathrm{~h}$ intertidal and subtidal collectors for the respective sampling period. Acrophase values are expressed relative to water level, and therefore represent time (h) to high tide

\begin{tabular}{|c|c|c|c|c|c|c|c|c|c|c|}
\hline \multirow[b]{2}{*}{ Sampling effort } & \multicolumn{5}{|c|}{ Spring tide period } & \multicolumn{5}{|c|}{ Neap tide period } \\
\hline & $\lambda(\mathrm{h})$ & $\theta(\mathrm{h})$ & $M$ & $A$ & $\mathrm{R}^{2}$ & $\lambda(\mathrm{h})$ & $\theta(\mathrm{h})$ & $M$ & $A$ & $\mathrm{R}^{2}$ \\
\hline Water level & 12.05 & - & 6.71 & 1.50 & 0.88 & 12.48 & - & 6.34 & 0.76 & 0.84 \\
\hline Plankton tows & - & -1.94 & 0.15 & 0.14 & 0.36 & - & -4.01 & 0.17 & 0.16 & 0.41 \\
\hline $2 \mathrm{~h}$ intertidal collectors & - & -2.78 & 0.18 & 0.14 & 0.19 & - & -2.93 & 3.90 & 2.95 & 0.61 \\
\hline $2 \mathrm{~h}$ subtidal collectors & - & -4.51 & 0.29 & 0.44 & 0.39 & - & -1.80 & 0.87 & 0.37 & 0.09 \\
\hline
\end{tabular}




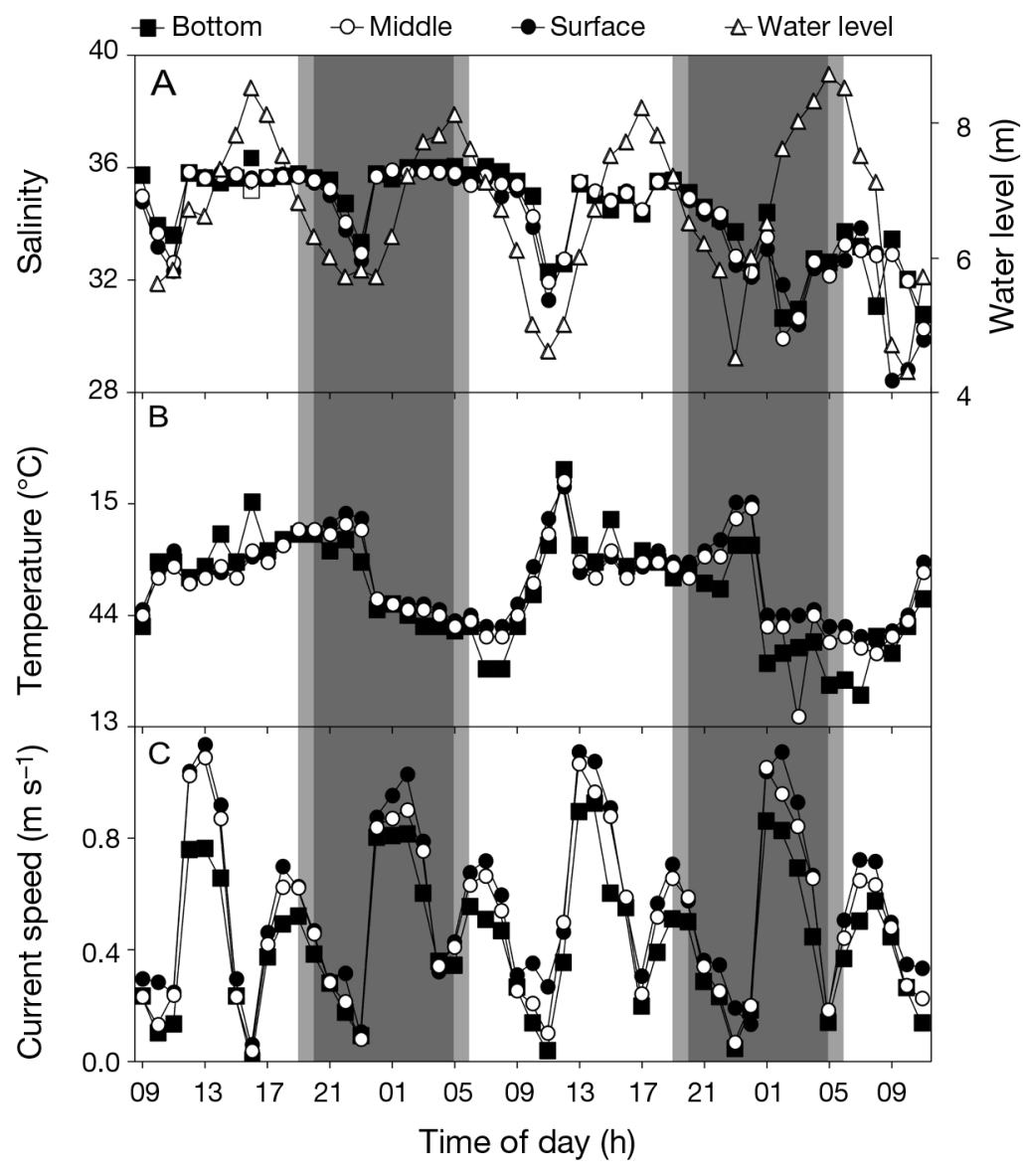

Fig. 4. Hydrological parameters during the spring tide period. (A) Salinity and water level, (B) temperature, and (C) current speed. Dark grey, light grey and unshaded areas represent dark, crepuscular and daylight hours, respectively
0.001) (Table 2). Cumulative settlement on $12 \mathrm{~h}$ collectors equalled settlement on $25 \mathrm{~h}$ collectors, suggesting that post-settlement secondary dispersal in less than $25 \mathrm{~h}$ was unlikely to occur during the neap tide period (Table 2).

\section{DISCUSSION}

Frequent sampling of available planktonic megalopae and settled megalopae requires high occurrences of both for these data to be meaningful. In order to deal with this constraint, we attempted to identify periods of high occurrence of megalopae beforehand and extended to 4 consecutive tidal cycles the effort of each sampling period. However, the low occurrences recorded only allowed for 1 spring and 1 neap tide period to be sampled. Nevertheless, the results presented in this study support hypotheses (1) and (4) under test: the majority of megalopae entering the estuary remained inside, and both upstream movement and settlement conformed to the conceptual model for brachyuran crabs. Density-dependent secondary dispersal of settled megalopae was not detected at high temporal resolution, and settlement was mainly intertidal, refuting hypotheses (2) and (3), respectively.

\section{Planktonic availability}

$(t=19.000, \mathrm{p}<0.05)$, without any significant light vs. dark difference $(t=2.053, \mathrm{p}=0.059)$ (Table 2 ).

The settlement patterns obtained during the neap tide period are in agreement with the conceptual model. Settlement on $2 \mathrm{~h}$ intertidal collectors was generally higher than on subtidal ones, with an average of 2.4 megalopae collector ${ }^{-1} \mathrm{~h}^{-1}$. Periodic regression analyses only revealed a tidal periodicity on intertidal collectors (Table 1, Fig. 7). Settlement peaks occurred soon after mid-flood tides, following hourly concentration maxima of megalopae in the plankton, with a peak lag of ca. $1 \mathrm{~h}$. By these times, salinity was high, temperature was low and current speed had started to decrease (Fig. 5). Significant light vs. dark settlement differences were not detected on intertidal $(t=-0.780, \mathrm{p}=0.454)$ or subtidal $(t=0.067, \mathrm{p}=0.948)$ $2 \mathrm{~h}$ collectors. However, significantly more megalopae settled on $12 \mathrm{~h}$ collectors sampling night-influenced flood tides, suggesting that light inhibition was only detectable with a cumulative effect $(\mathrm{t}=-4.757, \mathrm{p}<$
Supply levels of megalopae were similar to those of surface net flux during both spring and neap tide periods, which indicates that both measures correctly described megalopal abundances in the plankton. This supports the idea that the vast majority of megalopae that entered the estuary with flood tides remained within estuarine boundaries after ebb tides, as indicated by the low captures on passive nets facing ebb tides. Furthermore, both megalopal supply and surface net flux were significantly higher (by a factor of approximately 2) during the spring tide period, in accordance with the semilunar supply pattern proposed by Queiroga et al. (2006) for the Mira Estuary. This suggests that the decoupling between supply and settlement of shore crab megalopae previously reported for the Mira Estuary (Paula et al. 2006, Queiroga et al. 2006), and confirmed in the present study, is not an artefact caused by overestimation of 
planktonic abundances of megalopae during the spring tide period, as overestimation did not occur in these studies.

Hourly concentration of megalopae showed similar levels in both periods, which implies that the higher megalopal supply and net flux of the spring tide period did not result from higher concentrations of megalopae, but possibly from the higher water flux entering the estuary during that period. Patterns of hourly concentration of megalopae were similar during both periods and conformed to upstream movement of megalopae by STST. However, only during the neap tide period did megalopae occur in the water column preferentially during night-influenced flood tides, in complete agreement with the conceptual model. The higher amplitude changes in current speed of the spring tide period may have cued megalopae to swim also during daylight flood tides, overriding the swimming inhibition by light. Regarding upstream movement of megalopae, these results suggest that no deviations from the conceptual model that could explain the decoupling between supply and settlement of shore crab megalopae occurred during the spring and neap tide periods.

\section{Settlement}

Settlement of shore crab megalopae on the collectors showed a marked semilunar periodicity throughout the daily series, with maxima during neap tides, on days of waxing and waning moons. Despite the relatively lower settlement levels recorded, these results are in accordance with recent studies conducted in the same estuary (Paula et al. 2006, Queiroga et al. 2006); interannual fluctuations in larval recruitment and settlement levels are common in marine invertebrate species (e.g. Roughgarden et al. 1988). The general settlement pattern reported by all three studies conducted in the Mira Estuary deviates from that of the conceptual model for brachyuran crabs in the sense that settlement was not maximized when flood currents occurred in darkness. During this study, flood currents occuring in darkness mainly took place at spring tides. In fact, settlement maxima occurred during neap tides, when such co-occurrence was minimal. This suggests that processes other than light inhibition might be responsible for the settlement pattern of the shore crab in the Mira Estuary. Furthermore, the high
Table 2. Carcinus maenas. Mean $( \pm \mathrm{SE})$ daily captures of megalopae in passive plankton nets and on 12 and $25 \mathrm{~h}$ collectors (ind. collector ${ }^{-1} \mathrm{~d}^{-1}$ ). Captures in passive nets are presented for nets facing flood (supply) and ebb tides (ind. $\mathrm{d}^{-1}$ ), and as net flux (ind. net ${ }^{-1} \mathrm{~d}^{-1}$ ) at the water surface and bottom. Captures on $12 \mathrm{~h}$ collectors are presented for cumulative, light and dark periods. Student's $t$-test comparisons were made between captures in flood and ebb-facing nets, surface and bottom net fluxes, $25 \mathrm{~h}$ and cumulative $12 \mathrm{~h}$ collectors,

and light and dark $12 \mathrm{~h}$ collectors: ${ }^{*} \mathrm{p}<0.05,{ }^{* * *} \mathrm{p}<0.001$

\begin{tabular}{|lcccc|}
\hline & \multicolumn{3}{c}{ Spring tide period } & \multicolumn{2}{c|}{ Neap tide period } \\
Sampling effort & Mean & SE & Mean & SE \\
\hline Passive nets & & & & \\
$\quad$ Flood (Supply) & 1028.5 & $184.5^{*}$ & 555 & 434 \\
$\quad$ Ebb & 43.5 & 31.5 & 11 & 5 \\
Surface net flux & 974 & $218^{*}$ & 412 & 377 \\
$\quad$ Bottom net flux & 11 & 2 & 132 & 52 \\
12 h collectors & & & & \\
Light & 1.88 & 1.45 & 11.52 & $8.57^{* * *}$ \\
Dark & 0.63 & 0.70 & 36.03 & 25.19 \\
Cumulative & 2.50 & $1.50^{*}$ & 59.63 & 13.10 \\
25 h collectors & 0.13 & 0.33 & 53.38 & 18.72 \\
\hline
\end{tabular}




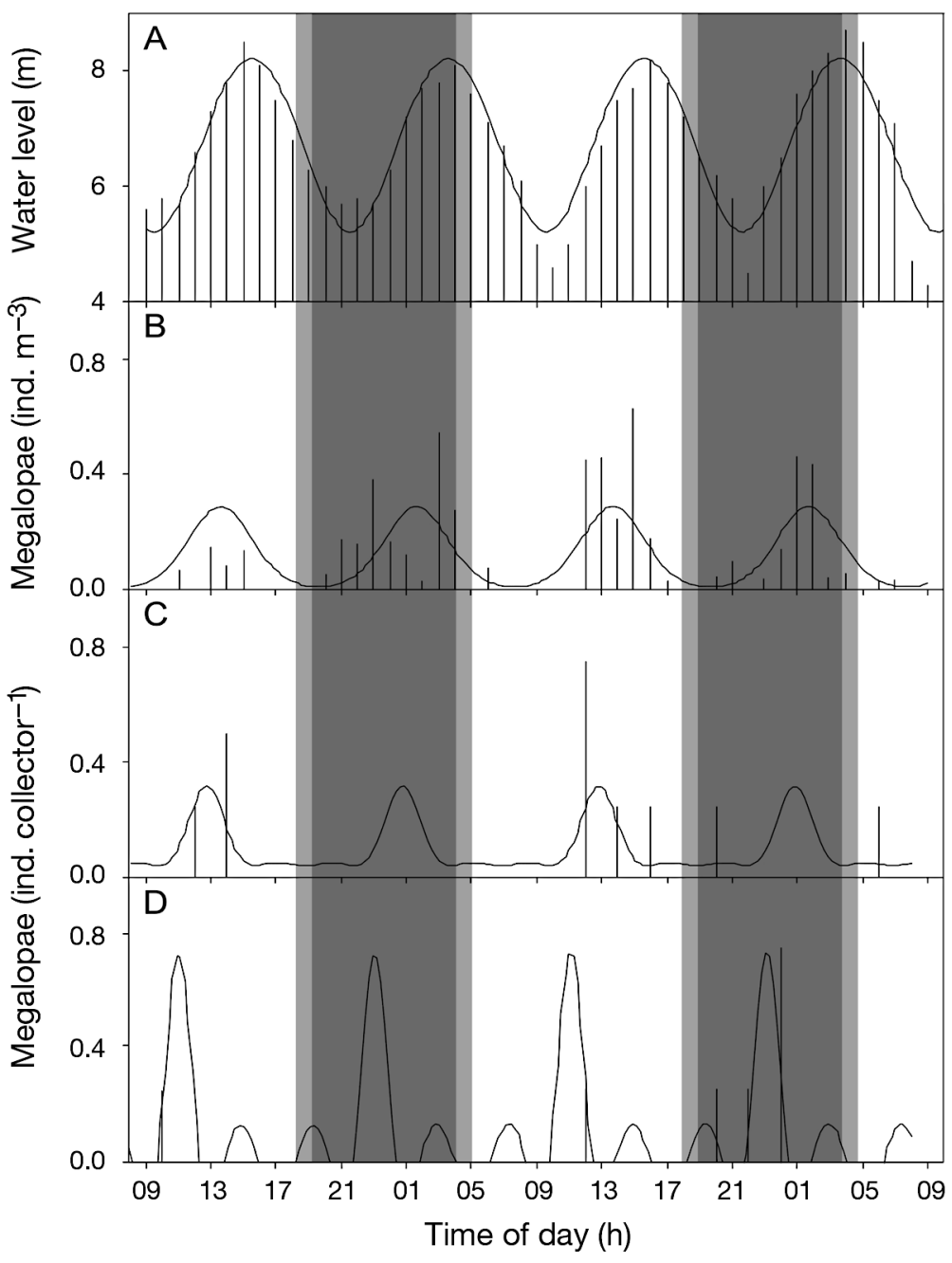

Fig. 6. Carcinus maenas. Mean megalopal captures during the spring tide period. (A) Water level. (B) Mean captures of megalopae in plankton tows. Mean settlement on (C) $2 \mathrm{~h}$ intertidal and (D) $2 \mathrm{~h}$ subtidal collectors. Curves represent fitting of sinusoidal models using nonlinear regression analysis (see Table 1). Dark grey, light grey and unshaded areas represent dark, crepuscular and daylight hours, respectively

correlation found between tidal amplitude and settlement suggests that tidal-related processes (e.g. turbulence) may be involved in such deviation from the conceptual model.

Settlement on collectors of higher temporal resolution followed the reported semilunar settlement pattern, thus being clearly decoupled from megalopal supply and surface net flux. These results confirm, at higher temporal resolution, the decoupling between supply and settlement of the shore crab recently reported for the Mira Estuary (Paula et al. 2006, Queiroga et al. 2006). Also in agreement with previous studies, settlement was higher on intertidal than on subtidal short-term collectors, supporting the idea that it mainly occurred high on the shore, where juvenile shore crabs are most abundant (Zeng et al. 1997, 1999, Silva et al. 2006). Although these results are predictable, based on the literature they are also essential to refute the hypothesis that settlement occurs subtidally, especially during spring tides, and thus masks the settlement patterns hitherto reported for the Mira Estuary. This indicates that the low settlement recorded during the spring tide period did not result from density-dependent secondary dispersal of settled megalopae, as virtually no megalopae initially settled, intertidally or subtidally. Therefore, the reported decoupling between supply and settlement did not result from failure in detecting settlement during the spring tide period, suggesting that it resulted instead from processes preventing such settlement.

On the other hand, during the neap tide period settlement occurred consistently on $2 \mathrm{~h}$ intertidal collectors, showing marked tidal and diel periodicities, in strict accordance with the conceptual model. Settlement peaks occured approximately $1 \mathrm{~h}$ after peaks of planktonic availability of megalopae. These patterns seem not to have been influenced by secondary dispersal of settled megalopae, as supported by the parallelism of cumulative settlement on $12 \mathrm{~h}$ collectors with that on $25 \mathrm{~h}$ collectors. This suggests that the decoupling pattern did not result also from unexpected behavioural settlement responses of megalopae to hydrological parameters during the neap tide period.

In summary, our results seem to corroborate, at higher temporal resolution, that supply of shore crab megalopae is decoupled from settlement in the lower Mira Estuary. Furthermore, they suggest that the observed decoupling did not result from incorrect estimation of megalopal abundances in the plankton, or from deviations from the conceptual model of reinvasion and settlement for brachyuran crabs in mesotidal systems. In fact, the results indicate that processes preventing settlement and capable of overriding megalopal responses to light intensities during spring tides may explain such decoupling. Queiroga et al. (2006) proposed that the competence state of megalopae might explain the decoupling between supply and settlement in the Mira Estuary. They suggested that supply from a pool of megalopae in an earlier stage of development during spring tides could result in a delay between supply and 




Fig. 7. Carcinus maenas. Mean megalopae captures during the neap tide period. (A) Water level. (B) Mean captures of megalopae in plankton tows. Mean settlement on (C) $2 \mathrm{~h}$ intertidal and (D) $2 \mathrm{~h}$ subtidal collectors. Curves represent fitting of sinusoidal models using nonlinear regression analysis (see Table 1). Dark grey, light grey and unshaded areas represent dark, crepuscular and daylight hours, respectively

settlement. Marked and consistent semilunar differences in development stages of megalopae are hard to conceive due to the heterogeneous nature of coastal waters where larvae develop (Pineda 2000). Furthermore, we conducted a pilot study in the Mira Estuary which revealed that such differences do not exist. In that study, 1 surface and 1 bottom passive plankton net was deployed facing flood tides and sampled every $24 \mathrm{~h}$ for $3 \mathrm{~d}$ at each moon phase from 27 April to 5 June, 2002. Ten megalopae were randomly sampled from each depth and moon phase and checked for development stage according to Gonzalez-Gordillo et al. (2004). Maxilliped stages 2 to 6 were identified during both spring and neap tides, with no different occurrences between such periods $\left(\chi^{2}=2.292, \mathrm{p}<0.01\right)$. Another explanation proposed by Queiroga et al.
(2006) was that higher turbulence levels during spring tides might prevent megalopae from settling in the lower Mira Estuary. Megalopae are known to respond to turbulence changes rather than absolute values (Welch et al. 1999, Pineda 2000, Welch \& Forward 2001). The higher amplitude changes in current speed values (an indirect measure of turbulence) registered during the spring tide period might have prevented megalopae from settling. This hypothesis is further supported by the high correlation found between daily settlement and days of lowest tidal amplitude, associated with lower turbulence levels (neap tides). Higher turbulences during the spring tide period may thus have cued megalopae to swim also during daylight flood tides, which prevented settlement and governed upstream movement and settlement events in the lower Mira Estuary during this study. This discussion further raises the question of what happens to most of the megalopae coming in as the peak supply during spring tides. We can speculate that they may be transported on consecutive flood tides and colonize more upstream areas with lower turbulence levels. Future studies should focus on megalopal responses to turbulence level, associated with tidal amplitude, and its interactions with light inhibition pressures for a better understanding of recruitment processes in mesotidal systems.

Acknowledgements. We are indebted to S. Geist and K. Kreutz for field and laboratory help and for creating a nice working atmosphere. We thank Mr. I. Gomes da Silva and I. Silva for their help with fieldwork, and 3 anonymous referees for critical comments that greatly improved the manuscript. We acknowledge a PhD grant to V.A. (SFRH/BD/10471/2002) funded by Fundação para a Ciência e a Tecnologia (FCT). This work is part of the 'ProRecruit - Shelf processes controlling recruitment to littoral populations in an eastern oceanic boundary: using barnacles and crabs as models' research project, also funded by FCT (No. POCTI/1999/BSE/36663). Financial support was allocated by FCT under the Support Community Framework III, Operational Programme for Science, Technology and Innovation.

\section{LITERATURE CITED}

Almeida MJ, Queiroga H (2003) Physical forcing of onshore transport of crab megalopae in the northern Portuguese upwelling system. Estuar Coast Shelf Sci 57:1091-1102

Amaral V, Paula J (2007) Carcinus maenas (Crustacea: Brachyura): influence of artificial substrate type and 
patchiness on estimation of megalopae settlement. J Exp Mar Biol Ecol 346:21-27

Batschelet E (1981) Circular statistics in biology. Academic Press, London

Blanton JO, Andrade FA (2001) Distortion of tidal currents and the lateral transfer of salt in a shallow coastal plain estuary (O Estuário do Mira, Portugal). Estuaries 24:467-480

Chatfield C (1996) The analysis of time series data: an introduction. Chapman \& Hall, London

Dawirs RR (1985) Temperature and larval development of Carcinus maenas (Decapoda) in the laboratory; predictions of larval dynamics in the sea. Mar Ecol Prog Ser 24: 297-302

De Vries MC, Tankersley RA, Forward RB, Kirbysmith WW, Luettich RA (1994) Abundance of estuarine crab larvae is associated with tidal hydrologic variables. Mar Biol 118: 403-413

Forward RB Jr, Tankersley RA (2001) Selective tidal-stream transport of marine animals. Oceanogr Mar Biol 39: 305-353

Forward $\mathrm{RB} \mathrm{Jr}$, Cohen $\mathrm{JH}$, Irvine RD, Lax JL and 5 others (2004) Settlement of blue crab Callinectes sapidus megalopae in a North Carolina estuary. Mar Ecol Prog Ser 269: $237-247$

Gonzalez-Gordillo JI, Rodriguez A, Queiroga H (2004) Characterization of the megalopal premoult stages of the green crab, Carcinus maenas (Decapoda, Portunidae), from laboratory culture. J Crust Biol 24:502-510

Little KT, Epifanio CE (1991) Mechanism for the re-invasion of an estuary by two species of brachyuran megalopae. Mar Ecol Prog Ser 68:235-242

Nagaraj M (1993) Combined effects of temperature and salinity on the zoeal development of the green crab, Carcinus maenas (Linnaeus, 1758) (Decapoda: Portunidae). Sci Mar $57: 1-8$

Paula J (1989) Rhythms of larval release of decapod crustaceans in the Mira Estuary, Portugal. Mar Biol 100: 309-312

Paula J, Silva IC, Francisco SM, Flores AV (2006) The use of artificial benthic collectors for assessment of spatial patterns of settlement of megalopae of Carcinus maenas (L.) (Brachyura: Portunidae) in the lower Mira Estuary, Portugal. Hydrobiologia 557:69-77

Pineda J (2000) Linking larval settlement to larval transport: assumptions, potentials and pitfalls. Oceanogr East Pac 1: 84-105

Editorial responsibility: Otto Kinne (Editor-in-Chief), Oldendorf/Luhe, Germany
Queiroga H (1998) Vertical migration and selective tidal stream transport in the megalopa of the crab Carcinus maenas. Hydrobiologia 376:137-149

Queiroga H, Costlow JD, Moreira MH (1994) Larval abundance patterns of Carcinus maenas (Decapoda, Brachyura) in Canal de Mira (Ria de Aveiro, Portugal). Mar Ecol Prog Ser 111:63-72

Queiroga H, Almeida MJ, Alpuim T, Flores AAV and 5 others (2006) Tide and wind control of megalopal supply to estuarine crab populations on the Portuguese west coast. Mar Ecol Prog Ser 307:21-36

Roughgarden J, Gaines S, Possingham H (1988) Recruitment dynamics in complex life cycles. Science 241:1460-1466

Silva IC, Dinis AM, Francisco SM, Flores AAV, Paula J (2006) Longitudinal distribution and lateral pattern of megalopal settlement and juvenile recruitment of Carcinus maenas (L.) (Brachyura, Portunidae) in the Mira River Estuary, Portugal. Estuar Coast Shelf Sci 69:179-188

Tankersley RA, McKelvey LM, Forward RB (1995) Responses of estuarine crab megalopae to pressure, salinity and light_implications for flood tide transport. Mar Biol 122: 391-400

Tankersley RA, Welch JM, Forward RB (2002) Settlement times of blue crab (Callinectes sapidus) megalopae during flood-tide transport. Mar Biol 141:863-875

Welch JM, Forward RB (2001) Flood tide transport of blue crab, Callinectes sapidus, postlarvae: behavioral responses to salinity and turbulence. Mar Biol 139:911-918

Welch JM, Forward RB Jr, Howd PA (1999) Behavioral responses of blue crab Callinectes sapidus postlarvae to turbulence: implications for selective tidal stream transport. Mar Ecol Prog Ser 179:135-143

Zeng C, Naylor E (1996) Occurrence in coastal waters and endogenous tidal swimming rhythms of late megalopae of the shore crab Carcinus maenas: implications for onshore recruitment. Mar Ecol Prog Ser 136:69-79

Zeng C, Naylor E (1997) Rhythms of larval release in the shore crab Carcinus maenas (Decapoda: Brachyura). J Mar Biol Assoc UK 77:451-461

Zeng C, Naylor E, Abello P (1997) Endogenous control of timing of metamorphosis in megalopae of the shore crab Carcinus maenas. Mar Biol 128:299-305

Zeng C, Abello P, Naylor E (1999) Endogenous tidal and semilunar moulting rhythms in early juvenile shore crabs Carcinus maenas: implications for adaptation to a high intertidal habitat. Mar Ecol Prog Ser 191:257-266

Submitted: May 31, 2006; Accepted: May 15, 2007

Proofs received from author(s): September 21, 2007 